\title{
TINDAK TUTUR PERLOKUSI DALAM DIALOG FILM “THE TEACHER'S DIARY" DENGAN SUBTITLE BAHASA INDONESIA
}

\author{
Febri Haryani, Asep Purwo Yudi Utomo \\ Program Studi Pendidikan Bahasa dan Sastra Indonesia \\ Fakultas Bahasa dan Seni \\ Universitas Negeri Semarang \\ febriha13@students.unnes.ac.id, aseppyu@mail.unnes.ac.id
}

\begin{abstract}
ABSTRAK
Tuturan sebagai bentuk komunikasi setiap individu memiliki makna dan maksud tertentu yang disampaikan oleh penutur kepada mitra tuturnya. Adanya bentuk tuturan tertentu dari penutur akan mempengaruhi pemahaman dan tanggapan dari mitra tuturnya. Dengan demikian, kajian ini bertujuan untuk mendeskripsikan bentuk tindak tutur perlokusi dalam film "The Teacher's Diary" dengan subtitle Bahasa Indonesia. Data dalam kajian ini diperloeh dari dialog adegan atau tuturan tokoh dalam film "The Teacher's Diary" dengan subtitle Bahasa Indonesia. Kajian ini menggunakan metode deskriptif kualitatif. Teknik pengumpulan data yang digunakan adalah teknik simak dan catat. Hasil dari kajian ini mengungkapkan bahwa dalam film "The Teacher's Diary" dengan subtitle Bahasa Indonesia mengandung bentuk tindak tutur perlokusi yang meliputi, membujuk, menipu, mendorong, membuat jengkel, menkut-nakuti, menyenangan, melegakan, mempermalukan, dan menarik perhatian. Hasil kajian ini, diharapkan dapat menambah khasanah keilmuan tentang pragmatik dan dapat memberikan pemahaman mengenai bentuk tindak tutur perlokusi untuk pembaca.
\end{abstract}

Kata kunci: kajian pragmatik, tindak tutur, perlokusi

\section{ABSTRACT}

Speech as communication shape from everyone has certain meanings and intentions conveyed by speaker to the speech partner. The existence of certain forms of speech will affect the understanding and response the speech partner. Thus, the purpose of this study is to describe speech acts of speech (perlocution) in the film "The Teacher's Diary" with Indonesian subtitles. The data in this study were obtained from the dialogue of scenes or speeches of the characters in the film. The method used in this study is descriptive qualitative. The techniques to data collection by observe attentively and note. The results of this study reveal that in the film "The Teacher's Diary" with Indonesian subtitles containing the act of speech acts of perlocution which includes acts of speech to persuade, deceive, encourage, irritate, frighten, delight, relieve, humiliate, and attract attention. The results of this study are expected to increaste the repertoire of scientific about pragmatics and provide an understanding of the form of speech acts of perlocution for the community.

Keywords: study pragmatics, speech act, perlocution.

\section{PENDAHULUAN}

Film merupakan gambar bergerak atau moving picture yang menjadi media komunikasi massa untuk mengomunikasikan realita yang ada dalam kehidupan (Saubani, 2018). Dari pernyataan tersebut, kita dapat mengetahui bahwa sebuah 
film merupakan sarana mengomunikasikan realita kehidupan. Wujud realita kehidupan tersebut tentu dapat kita lihat melalui adegan serta dialog tuturkan tokoh yang dimuat didalamnya. Tuturan tokoh di dalam adegan film yang membentuk jalan cerita, menjadi salah satu kemenarikan bagi penonton untuk memahami alur cerita. Kemenarikan tersebut disebabkan oleh adanya bentuk tuturan yang memiliki maksud beragam dengan cara penyampaian yang beragam pula, disesuaikan dengan tujuan adanya tuturan tersebut atau maksud yang ingin disampaikan.

Salah satu film yang menarik untuk dikaji pada aspek wujud dan jenis tuturannya adalah film berjudul "The Teacher's Diary" dengan subtitle Bahasa Indonesia karya Nithiwat Tharathon. Di dalam film yang berlatarkan kehidupan pendidikan tersebut, dapat ditemukan berbagai bentuk tuturan seorang pendidik, peserta didik, serta orang tua, yang cukup menarik untuk dikaji dan dipahami. Berbagai bentuk tuturan yang ada di dalam dialog tokoh film tersebut memiliki keunikan seperti bentuk tuturan dan daya pengaruhnya untuk mitra tuturnya atau lawan bicara dalam adegan film tersebut. Adanya hal tersebut tuturan dalam film ini akan cocok untuk dikaji dengan teori tindak tutur perlokusi. Dengan demikian, kajian ini akan fokus pada pembahasan bentuk tindak tutur perlokusi dalam dialog film "The Teacher's Diary" yang telah diberi subtitle Bahasa Indonesia.

Sendilatta (2013) mengatakan bahwa tindak tutur adalah sebuah proses aktivitas berbahasa yang berupa kalimat dalam bentuk ujaran atau percakapan antara penutur dan mitra tutur untuk menghasilkan suatu tindakan. Pendapat lain tentang tindak tutur dikatakan oleh Chaer dalam (Wiranty 2015) bahwa tindak tutur (speech act) adalah gejala individu yang bersifat psikologis dan berlangsungnya ditentukan oleh kemampuan bahasa si penutur dalam menghadapi situasi tertentu. Adapun, Leech (dalam Guntara, 2016) mengungkapkan bahwa dalam tindak tutur mempertimbangkan lima aspek situasi tutur mencakup penutur, mitra tutur, konteks tuturan, tujuan tuturan, tindak tutur sebagai sebuah tindakan atau aktivitas dan sebagai produk tindak verbal.

Pengklasifikasian rangkap tiga terhadap tindak-tindak dalam bertutur ada tiga jenis tindakan. Austin (dalam Pratiwi dkk, 2016) mengemukakan bahwa tindak lokusi, tindak ilokusi, dan tindak perlokusi merupakan klasifikasi jenis tindak tutur. Pertama, tindak tutur lokusi. Adhiguna (2019) mengungkapkan, tindak tutur yang digunakan untuk mengungkapkan sesuatu merupakan jenis tindak tutur lokusi. Menambahkan teori tersebut, (Anggreani dalam Oktavia, 2019) mengungkapkan tindak tutur lokusi atau the act of saying something merupakan tindak tutur yang maknanya dapat dilihat sesuai kategori gramatikal seperti kalimat berita, kalimat perintah, dan kalimat tanya. Kedua, tindak tutur ilokusi. Menurut Chaer (dalam Istiqomah, 2017) tindak tutur ilokusi berkenaan dengan pemberian izin, mengucapkan terima kasih, menyuruh, menawarkan, dan menjanjikan yang diidentifikasikan dengan kalimat performatif yang eksplisit. Klasifikasi tindak tutur ilokusi yang disampaiakn oleh Anggreani (dalam Oktavia, 2019) meliputi tindak 
tutur asertif, tindak tutur direktif, tindak tutur komisif, tindak tutur ekspresif, dan tindak tutur deklarasi. Ketiga, tindak tutur perlokusi. Dikatakan oleh Musyafir (2015) bahwa tindak tutur yang berfungsi mengakibatkan efek pada mitra tutur disebut tindak tutur perlokusi. Hermintoyo (dalam Oktavia, 2019) menyampaikan bahwa efek atau daya tuturan itu dapat ditimbulkan oleh penutur secara sengaja atau tidak sengaja. Ungkapan tentang tindak tutur perlokusi tersebut sejalan dengan pendapat Puspita Nagari (2020) bahwa tindak tutur perlokusi ditimbulkan baik secara disengaja atau tidak disengaja, serta tuturan perlokusi ini dapat memberikan efek maupun respon yang berbeda-berda terhadap petuturnya.

Melengkapi rumusan tentang tindak tutur perlokusi diatas, Searle (dalam Wijayanti, 2014) memberikan pengelompokkan tindak perlokusi menjadi tiga jenis. 1). Tindak tutur perlokusi verbal, yakni tanggapan dan efek yang ditunjukkan oleh lawan tutur dalam bentuk menerima atau menolak maksud penutur dengan ucapan verbal, misalnya menyangkal, melarang, tidak mengizinkan, mengucapkan terima kasih dan meminta maaf. 2). Tindak tutur perlokusi nonverbal, yaitu tanggapan dan efek yang ditunjukkan oleh lawan tutur dalam bentuk gerakan, seperti mengangguk, menggeleng, tertawa, senyuman, sedih dan bunyi decakan mulut. 3). Tindak tutur verbal nonverbal, yaitu tanggapan dan efek yang ditunjukkan oleh lawan tutur dalam bentuk ucapan verbal yang disertai dengan gerakan nonverbal, misalnya berbicara sambil tertawa atau tindakan-tindakan lain yang diminta oleh lawan tutur. Leech (dalam Nabilla, 2014) mengungkapkan beberapa verba yang dapat menjadi tanda bahwa tindak tutur tersebut adalah tindak tutur perlokusi meliputi membujuk, menipu, mendorong, membuat jengkel, menakut-nakuti, menyenangkan, melegakan, mempermalukan, menarik perhatian dan sebagainya.

Beberapa penelitian terdahulu yang relevan dengan penelitian saat ini untuk dapat dijadikan acuan pengembangan, antara lain sebagai berikut. Oktaviani (2015) dengan judul penelitian "Tindak Tutur Lokusi Dan Perlokusi Dalam Dialog Film 5 Cm Karya Rizal Mantovani." Pada tahun selanjutnya, Fitriah dan Fitriani (2016) membuat penelitian berjudul "Analisis Tindak Tutur dalam Novel Marwah di Ujung Bara Karya R.H Fitriyadi.” Atanti (2016) juga melakukan penelitian, dengan memberi judul penelitian "Analisis Tindak Tutur dalam Novel Jegingger Berkisar Merah Edisi Banyumasan Karya Ahmad Tohari." Dongalemba (2016) yang melakukan penelitian dengan judul "Aspek-aspek Perlokusi Dalam Film Spy Karya Paul Feig." Masih pada tahun yang sama, Awon (2016) dengan judul penelitian "Tindak Perlokusi Dalam Film Eat, Pray, Love Karya Ryan Murphy Suatu Analisis Pragmatik." Selanjutnya, Mawarti (2018) dengan judul penelitian "Analisis Tindak Tutur dalam Novel Keluarga Tak Kasat Mata Karya Bonaventura Genta Kajian Pragmatik dan Relevansinya Sebagai Alternatif Bahan Ajar Bahasa Indonesia Di SMP." Tahun selanjutnya, Putra dan Yuana (2019) melakukan penelitian dengan judul “Analisis Lokusi Ilokusi Perlokusi dalam Drama Koe Koi.” Tumalun dkk. (2019) melakukan penelitian dengan judul "Tindak Penolakan dalam Film Twilight Karya Chaterine Hardwicke (Suatu Analisi Pragmatik)." Dan terakhir, Puspita Nagari 
(2020) dengan judul penelitian "Tindak Tutur Perlokusi dan Prinsip Kerja Sama dalam Drama Meteor Garden 2018 Episode 1-10 karya Lin Helong."

Dari beberapa penelitian yang disebutkan di atas, terdapat persamaan dan perbedaan dengan penelitian yang dilakukan saat ini. Persamaan yang ditemui adalah jenis kajiannya yang mengarah pada kajian pragmatik tindak tutur perlokusi. Di dalam penelitian yang terdahulu, penulis membuat penelitian dengan fokus kajian pada beberapa jenis tindak tutur dengan teori pragmatik yang beragam. Namun, dalam kajian ini fokus kajiannya hanya pada satu jenis tindak tutur, yaitu tindak tutur perlokusi. Teori tindak tutur perlokusi yang digunakan dalam kajian ini untuk menglasifikasikan data adalah teori dari Leech pada tahun 1983 tentang bentuk verba yang menandai bentuk tindak tutur perlokusi.

Tujuan dari kajian ini adalah untuk mendeskripsikan bentuk tindak tutur perlokusi yang ditemukan pada tuturan adegan film berjudul "The Teacher's Diary" dengan subtitle Bahasa Indonesia. Kajian ini diharapkan dapat memberi manfaat baik secara teoretis maupun secara praktis. Secara teoretis hasil kajian ini diharapkan dapat membawa manfaat dalam perkembangan kajian tindak tutur perlokusi dalam bidang pragmatik. Adapun secara praktis kajian ini diharapkan akan menambah pemahaman masyarakat mengenai wujud tindak tutur perlokusi yang dapat ditemukan dalam film.

\section{METODE}

Kajian tindak tutur perlokusi dalam film berjudul "The Teacher's Diary" dengan subtitle Bahasa Indonesia menggunakan metode penelitian deskriptif kualitatif. Pengumpulan data dalam penelitian ini dilakukan dengan teknik simak dan catat yang meliputi bahasa tulis (subtitle) dari tuturan lisan tokoh. Data yang telah terkumpul tersebut kemudian ditranskripsikan dan dikaji dengan teori tentang tindak tutur perlokusi. Agar penelitian ini mempunyai landasan teori yang kuat dan bisa diterima secara logis oleh pembaca, maka dalam pembahasan dan hasil kajian, temuan atau data akan dideskripsikan dan dikaji dengan dasar teori tindak tutur perlokusi dari Leech dengan membandingkan hasil kajian penelitian sebelumnya.

\section{HASIL DAN PEMBAHASAN}

Pada film berjudul "The Teacher's Diary" dengan subtitle Bahasa Indonesia dapat ditemukan beberapa jenis tindak tutur antara lain tindak tutur perlokusi membujuk, menipu, mendorong, membuat jengkel, menkut-nakuti, menyenangan, melegakan, mempermalukan, dan menarik perhatian. Tuturan perlokusi yang ditemukan dalam film berjudul "The Teacher's Diary" dengan subtitle Bahasa Indonesia sejumlah 26 tuturan. Pada jenis tindak tutur perlokusi membujuk ditemukan lima data, pada jenis tindak tutur perlokusi menipu ditemukan satu data, pada jenis tindak tutur perlokusi mendorong ditemukan tiga data, pada jenis tindak tutur perlokusi membuat jengkel ditemukan lima data, pada jenis tindak tutur perlokusi menakut-nakuti ditemukan satu data, pada jenis tindak tutur 
menyenangkan ditemukan tiga data, pada jenis tindak tutur perlokusi melegakan ditemukan empat data, pada jenis tindak tutur perlokusi mempermalukan ditemukan satu data, dan pada jenis tindak tutur perlokusi menarik perhatian ditemukan tiga data.

Data hasil kajian tindak tutur perlokusi dalam film berjudul "The Teacher's Diary" dengan subtitle Bahasa Indonesia dapat diklasifikasikan sebagai berikut, dengan mengkaji salah satu kutipan dalam tiap jenisnya.

\section{Tindak Tutur Perlokusi Membujuk}

Bentuk tindak tutur perlokusi membujuk (persuade) diidentifikasikan dengan tuturan yang menjelaskan alasan-alasan yang baik untuk membuat seseorang melakukan sesuatu (Istiqomah, 2017). Beriikut adalah kutipam tindak tutur menujuk.

\section{Tuturan:}

Kepala Sekolah : "Saat ini posisi guru PE kami sudah diisi."

Guru Song : "Saya bisa menjadi asisten guru. Saya bisa membuat kerajinan tangan dan kesenian. Fotokopi, mengirim faks, saya akan melakukan apapun."

(menit 00.02.04)

Situasi: Tuturan di atas merupakan percakapan antara Guru Song dan Kepala Sekolah, ketika Guru Song melamar pekerjaan sebagai guru di sekolah tersebut.

Pada kutipan tuturan di atas menunjukkan adanya tuturan perlokusi membujuk yang dituturkan oleh Guru Song. Ketika Kepala sekolah mengatakan bahwa posisi guru olahraga sudah penuh, Guru Song mencoba menawarkan hal yang ia bisa lakukan dengan tuturan "Saya bisa menjadi asisten guru. Saya bisa membuat kerajinan tangan dan kesenian. Fotokopi, mengirim faks, saya akan melakukan apapun." Tuturan tersebut memiliki maksud membujuk untuk mempengaruhi Kepala Sekolah agar memberinya pekerjaan atau menerimanya bekerja di sekolah tersebut.

Hasil analisis tersebut, melengkapi hasil penelitian sebelumnya, yang dilakukan oleh Mawarti, (2018) yang mengungkapkan tindak tutur perlokusi sebagai produk tindak verbal. Tuturan yang disampaikan oleh Windari pada Genta dalam hasil penelitian sebelumnya tersebut, sebetulnya juga mengandung tuturan perlokusi yang memberi efek mitra tutur menjadi terbujuk. Seperti yang ada dalam analisis ini, bahwa tuturan permintaan atau permohonan termasuk ke dalam jenis tindak tutur perlokusi membujuk.

\section{Tindak Tutur Perlokusi Menipu}

Bentuk tindak tutur perlokusi menipu (deceive) diidentifikasikan dengan adanya tuturan yang tidak benar untuk mendapat kepercayaan seseorang (Istiqomah, 2017). Berikut adalah kutipan tindak tutur menipu. 


\section{Tuturan:}

Ayang Chon : "Dia tidak sekolah hampir setahun. Tidak ada yang bisa menerimanya."

Guru Song : "Jangan khawatir. Saya kenal kepala sekolahnya, kami sangat dekat seperti keluarga."

(menit 00.48.21)

Situasi: Tuturan di atas merupakan percakapan antara Ayah Chon dengan Guru Song ketika Guru Song meminta agar Chon kembali bersekolah.

Pada kutipan Tuturan di atas menunjukkan bahwa Guru Song mencoba meyakinkan Ayah Chon untuk bisa mengajak Chon kembali bersekolah. Tuturan Guru Song dilakukan dengan tuturan yang membohongi ayah Chon bahwa ia mengenal dekat kepala sekolah jadi akan tidak masalah jika Chon kembali bersekolah. Tindak tutur Guru Song tersebut merupakan tuturan yang digunakan untuk meipu Ayah Chon agar mempengaruhi pikiran dan keputusan dari Ayah Chon.

Hasil analisis tersebut sesuai dengan hasil penelitian sebelumnya yang dilakukan oleh Puspita Nagari, (2020) bahwa tindak tutur membohongi atau menipu dapat memberi efek mendorong mitra tutur.

\section{Tindak Tutur Perlokusi Mendorong}

Bentuk tindak tutur perlokusi mendorong (encourage) diidentifikasikan dengan tuturan yang membuat suatu hal terjadi atau berkembang dengan memberikan dukungan, keberanian, maupun harapan (Istiqomah, 2017). Berikut adalah kutipan tindak tutur mendorong.

\section{Tuturan:}

Guru Ann : "Siapa saja yang bisa menyelesaikan duluan dengan benar, akan mendapat bintang. Satu, dua, tiga, mulai!" (menit 00.31.19)

Situasi: Tuturan di atas diucapkan oleh Guru Ann ketika selesai memberikan soal di papan tulis kelas.

Pada kutipan tuturan di atas menunjukkan bahwa Guru Ann menggunakan tindak tutur perlokusi untuk mendorong lawan bicaranya atau muridnya. Hal itu dapat dilihat dengan adanya tuturan pemberian penghargaan bagi murid-murid, dengan maksud membuat murid-murid segera melakukan kegiatan menjawab soal dengan benar.

Berdasarkan analisis di atas, terdapat persamaan dengan hasil penelitian sebelumnya yang dilakukan oleh Dongalemba, (2016) yang menyebutkan wujud tindak tutur perlokusi mendorong. Wujud tindak tutur perlokusi mendorong tersebut dibuktikan dengan adanya efek pada mitra tutur untuk mengikuti dan mempercayakan kata-kata penutur.

\section{Tindak Tutur Perlokusi Membuat Jengkel}

Bentuk tindak tutur perlokusi membuat jengkel (irritate) dapat diidentifikasikan dengan adanya tuturan dan hal-hal yang terus menerus 
menganggu, menyinggung, atau membuat marah seseorang (Istiqomah, 2017). Berikut adalah kutipan tindak tutur membuat jengkel.

\section{Tuturan:}

Kepala Sekolah : "Hapus tatonya sekarang."

Guru Ann : "Saya tidak bisa melakukannya."

Kepala Sekolah : "Lakukan!"

Guru Ann : "Tidak, saya tidak mau."

Kepala Sekolah : "Kalau kamu tidak melakukannya, saya kirim kamu ke sekolah rumah kapal kami."

Guru Ann : "Berikan saya tenggang waktu dua hari agar saya ada waktu untuk mengemasi barang-barang saya."

(menit 00.02.10)

Situasi: Tuturan di atas merupakan percakapan antara Kepala Sekolah dengan Guru Ann ketika Guru Ann mendapat peringatan tentang tato bintang di tangannya oleh Kepala Sekolah.

Pada kutipan tuturan di atas dapat menunjukkan bahwa baik tuturan antara Guru Ann dan Kepala Sekolah memberi pengaruh kepada lawan bicaranya menjadi jengkel. Guru Ann yang tidak mau menghapus tato bintang di tangannya, membuat Kepala Sekolah mengancamnya untuk memindahkannya ke sekolah kapal. Adanya ancaman Kepala sekolahpun membuat Guru Ann menjadi jengkel dan memilih melewati tantangan dengan siap dipindahkan. Hal tersebut mengungkapkan bahwa tuturan Kepala Sekolah merupakan tindak tutur perlokusi membuat jengkel.

Analisis di atas memiliki persamaan dengan hasill penelitian yang dilakukan Awon, (2016) yang menemukan wujud tindak tutur perlokusi menjengkelkan. Tindak tutur perlokusi menjengkelkan tersebut timbul pada percakapan dua orang yang membuat seseorang merasa terganggu, jengkel serta marah.

\section{Tindak Tutur Perlokusi Menakut-nakuti}

Bentuk tindak tutur perlokusi menakut-nakuti (frighten) dapat diidentifikasikan dengan adanya tuturan yang mengancam atau menakuti adanya keberadaan seseorang (Istiqomah, 2017). Berikut adalah kutipan tuturan menakutnakuti.

\section{Tuturan:}

Kepala Sekolah : "Kau harus mencoba lebih keras. Kontraknya hanya setahun. Kalau nilai di semester dua tidak meningkat saya tidak akan memperbarui kontrakmu." (menit 00.50.36)

Situasi: Tuturan di atas merupakan tuturan Kepala Sekolah kepada Guru Song ketika Kepala Sekolah mengecek hasil belajar murid di sekolah kapal yang diserahkan Guru Song tidak memuaskan.

Pada kutipan tuturan yang disampaikan Kepala Sekolah mengandung bentuk tindak tutur perlokusi menakut-nakui. Hal tersebut dadap dilihat dari adanya 
ancaman atau desakan yang diucapkan oleh Kepala Sekolah yang digunakan untuk menakut-nakuti Guru Song untuk tidak diperpanjang masa kerjanya.

Hasil analisis tersebut sesuai dengan hasil penelitian yang dilakukan oleh Tumalun dkk. (2019) yang mengemukakan tindak tutur untuk membuat takut mitra tutur. Adanya efek merasa takut tersebut disebabkan oleh adanya tuturan yang penuh desakan.

\section{Tindak Tutur Perlokusi Menyenangkan}

Bentuk tindak tutur menyenangkan atau menghibur (amuse) dapat diidentifikasikan dengan adanya tuturan menyenangkan hati atau membuat tertawa seseorang. (Istiqomah, 2017). Berikut adalah kutipan tindak tutur menyenangkan.

\section{Tuturan:}

Guru Ann : "Jika Anda tidak keberatan, saya ingin mengajar di rumah kapal lagi."

Kepala Sekolah : "Tidak sama sekali, justru saya senang. Guru yang di sana kurang baik, jika anda kembali ke sana, saya tidak perlu mengkhawatirkan ajaran baru lagi... Guru yang baik selalu dicari."

(menit 01.03.06)

Situasi: Tuturan di atas merupakan percakapan antara Guru Ann dan Kepala Sekolah ketika Guru Ann kembali dan meminta izin untuk mengajar kembali di sekolah kapal.

Pada kutipan tuturan di atas menunjukkan adanya wujud tindak tutur perlokusi menyenangkan pada tuturan Kepala Sekolah kepada Guru Ann. Penerimaan dan pujian yang sampaikan oleh Kepala Sekolah memberikan pengaruh terhadap Guru Ann, yaitu menjadi senang karena diterima dengan baik untuk mengajar lagi oleh Kepala Sekolah.

Berdasarkan analisis tersebut, terdapat persamaan dari hasil penelitian yang dilakukan oleh Atanti, (2016) bahwa tindak tutur perlousi menyenangkan dapat ditemui pada ungkapan perasaan bahagia penutur. Ungkapan bahagia dari penutur tersebut juga mempengaruhi perasaan mitra tuturnya untuk merasa senang.

\section{Tindak Tutur Perlokusi Melegakan}

Bentuk tindak tutur melegakan dapat diidentifikasikan dengan adanya tuturan yang mengesankan (impress) berupa tuturan yang membuat orang lain merasa puas dan kagum (Istiqomah, 2017). Berikut adalah kutipan tindak tutur melegakan.

\section{Tuturan:}

Guru Ann : "Akhirnya kau lulus. Kau harus lakukan yang terbaik untuk menolong Ayahmu memancing, oke?"

Chon : "Tidak perlu mengkhawatirkan itu. Aku akan menjadi nelayan yang sangat pandai matematika di sini!"

(menit 01.23.19) 
Situasi: Tuturan di atas merupakan percakapan antara Guru Ann dengan Chon ketika hari pengumuman kelulusan sekolah.

Pada kutipan tuturan di atas terdapat bentuk tindak tutur perlokusi, yaitu pada tuturan Chon kepada Guru Ann. Chon yang mengungkapkan bahwa Guru Ann tidak perlu mengkhawatirkannya, karena dia akan menjadi nelayan yang pandai matematika di daerah itu memberikan pengaruh perasaan lega kepada Guru Ann untuknya.

Hasil analisis tersebut sesuai dengan hasil penelitian terdahulu yang dilaukan oleh Putra dan Yuana, (2019) bahwa fungsi yang memusatkan perhatian pada keinginan-keinginan sang pembicara yang dilakukan atau dipikirkan oleh sang penyimak, merupakan bukti bentuk tuturan tersebut adalah tuturan perlokusi. Kesesuaian dalam penelitian ini adalah tuturan Chon pada Guru Ann yang mengandung pemusatan perhatian pada keinginan penutur. Dengan demikian tindak tutur tersebut merupakan tindak tutur perlokusi, yang memberi daya pengaruh perasaan lega.

\section{Tindak Tutur Perlokusi Mempermalukan}

Bentuk tindak tutur mempermalukan (embarrass) diidentifikasikan dengan adanya tuturan berupa olokan atau candaan yang menunjukkan kekurangan sehingga membuat seseorang merasa terkucil (Istiqomah, 2017). Berikut adalah kutipan tindak tutur mempermalukan.

\section{Tuturan:}

Kepala Sekolah : "Hei, itu untuk anak-anak, kenapa kau menaikinya? Nanti bisa rusak. Lebih baik kamu ke sini." (menit ke 00.01.12)

Situasi: Tuturan di atas disampaikan oleh Kepala Sekolah saat melihat Guru Song sedang memainkan fasilitas olahraga sekolah yang disediakan untuk anak-anak.

Pada kutipan tuturan di atas, tuturan Kepala Sekolah yang ditujukan untuk Guru Song yang sedang memainkan fasilitas olah raga untuk anak-anak mengandung pernyataan yang membuat Guru Song malu di hadapannya. Hal tersebut menunjukkan bahwa tuturan Kepala Sekolah tersebut merupakan jenis tindak tutur perlokusi mempermalukan.

Analisis tersebut melengkapi hasil penelitian terdahulu yang dilakukan oleh Fitriah dan Fitriani, (2016) tentang tindak tutur perlokusi verbal. Dalam penelitian terdahulu ditemukan maksud perlokusi verbal melarang. Sedangkan dalam analisis ini, tuturan melarang merupakan tindak tutur yang memiliki pengaruh untuk mempermalukan mitra tutur. Sehingga dalam penelitian ini, verba melarang masuk ke dalam jenis tindak tutur perlokusi mempermalukan.

\section{Tindak Tutur Perlokusi Menarik Perhatian}

Bentuk tindak tutur menarik perhatian (attract attention) dapat diidentifikasikan dengan adanya tuturan yang mengagumkan atau menarik 
perhatian seseorang (Istiqomah, 2017). Berikut adalah kutipan tindak tutur menarik perhatian.

\section{Tuturan:}

Guru Song : “Gurunya sudah ada di sini. Ayo sekolah! Ikut dengan saya! Semua orang tua yang punya anak, sekolahnya sudah dibuka!" (menit ke 00.10.46)

Situasi: Tuturan di atas disampaikan oleh Guru Song saat ia mengelilingi pemukiman dengan perahu untuk mendapatkan murid.

Pada kutipan tuturan di atas menunjukkan bahwa Guru Song sedang memberi informasi untuk orang tua dan anak-anak bahwa sekolah sudah di buka. Adanya tindakan menginformasikan sesuatu hal tersebut menunjukkan bahwa dalam tuturan tersebut mengandung sebuah tindak tutur perlokusi menarik merhatian lawan bicara. Dengan demikian tuturan Guru Song dalam kutipan tersebut merupakan bentuk tindak tutur perlokusi menaik perhatian.

Berdasarkan analisis tersebut, terdapat persamaan dari hasil penelitian sebelumnya yang dilakukan oleh Oktaviani, (2015) bahwa dalam tuturan perlokusi tersebut terdapat hal memberitahukan kepada mitra tutur. Pemberi tahuan yang adalam penelitian ini memiliki maksud untuk menarik perhatian mitra tuturnya. Sehingga dalam penelitian ini tuturan memberitahukan termasuk ke dalam jenis tindak tutur perlokusi menarik perhatian.

\section{PENUTUP}

\section{Simpulan}

Berdasarkan hasil kajian dan pembahasan yang dilakukan, dapat disimpilkan bahwa dalam dialog film berjudul "The Teacher's Diary" dengan subtitle Bahasa Indonesia mengandung beberapa bentuk tindak tutur perlokusi. Adapun bentuk tindak tutur perlokusi verba yang ditemukan meliputi tindak tutur perlokusi membujuk, menipu, mendorong, membuat jengkel, menkut-nakuti, menyenangan, melegakan, mempermalukan, dan menarik perhatian. Jumlah data tuturan perlokusi yang ditemukan adalah sebanyak 26 tuturan yang termasuk ke dalam bentuk tindak tutur perlokusi yang berbeda-beda.

\section{Saran}

Berdasarkan hasil penelitian yang telah dilakukan, saran yang dapat disampaikan untuk pembaca dan peneliti adalah sebagai berikut. Untuk pembaca, disarankan agar menjadikan hasil kajian ini sebagai bacaan untuk menambah pengetahuan mengenai ilmu pragmatik, khususnya terkait tindak tutur perlokusi. Adapun saran untuk peneliti selanjutnya, disarankan untuk mengembangkan penelitian ini pada aspek bahasan tindak tutur yang lain. Adanya kekurangan cakupan pembahasan dalam kajian ini semoga dapat membuat peneliti tergerak untuk memberikan perkembangan di penelitian yang akan dilakukan selanjutnya. 


\section{DAFTAR PUSTAKA}

Adhiguna, I. M. P., Susrawan, I. N. A., \& Erawan, D. G. B. (2019). Analisis Tindak Tutur Lokusi, Ilokusi, dan Perlokusi dalam Proses Pembelajaran Bahasa Indonesia di Kelas XI MIPA 7 SMA N 7 Denpasar Tahun Pelajaran 2018/2019. Jurnal Bakti Saraswati (JBS): Media Publikasi Penelitian dan Penerapan Ipteks, 8(2), 204-211.

Awon, P. (2016). Tindak Perlokusi Dalam Film Eat, Pray, Love Karya Ryan Murphy Suatu Analisis Pragmatik. Jurnal Elektronik Fakultas Sastra Universitas Sam Ratulangi, 4(5).

Atanti, S. (2016). Analisis Tindak Tutur dalam Novel Jegingger Berkisar Merah Edisi Banyumasan Karya Ahmad Tohari (Doctoral dissertation, PBSJ-FKIP).

Dongalemba, R. M. (2016). Aspek-aspek Perlokusi dalam Film Spy Karya Paul Feig. Jurnal Elektronik Fakultas Sastra Universitas Sam Ratulangi, 4(2).

Fitriah, F., \& Fitriani, S. S. (2017). Analisis Tindak Tutur dalam Novel Marwah di Ujung Bara Karya R.H. Fitriadi. Master Bahasa, 5(1), 51-62.

Guntara, R. (2016). Perlocutionary Act dalam Percakapan Film Furious 7 Kajian Pragmatik (Doctoral dissertation, Universitas Widyatama).

Istiqomah Pramudika, D. (2017). Perlokusi Tindak Tutur Ekspresif dalam Drama Wakamonotachi [若者たち] ドラマにおける表出的の発話媒介行為 (Kajian Pragmatik) (Doctoral dissertation, Universitas Diponegoro).

Mawarti, A. (2018). Analisis Tindak Tutur dalam Novel Keluarga Tak Kasat Mata Karya Bonaventura Genta Kajian Pragmatik dan Relevansinya Sebagai Alternatif Bahan Ajar Bahasa Indonesia di SMP. Prodi Bahasa dan sastra Indonesia Universitas PGRI Yogyakarta.

Musyafir, U. S. (2015). Analisis Tindak Tutur Perlokusi pada Kumpulan Cerpen "Bibir" Karya Bakdi Soemanto. Kreatif, 18(1), 24-33. http://jurnal.untad.ac.id/jurnal/index.php/Kreatif/article/view/4324

Nabilla, V. (2014). Makna Semantik dan Pragmatik Tindak Tutur Ilokusi Direktif dalam Naskah Film Chef: Kajian Semantik Pragmatik (Doctoral Dissertation, Universitas Widyatama).

Oktavia, W. (2019). Tindak Tutur Perlokusi dalam Album Lirik Lagu Iwan Fals: Relevansinya terhadap Pembentukan Karakter. Lingua, 15(1), 1-10.

Oktaviani, S. (2015). Tindak Tutur Lokusi Dan Perlokusi Dalam Dialog Film $5 \mathrm{Cm}$ Karya Rizal Mantovani (Doctoral dissertation, Universitas Muhammadiyah Surakarta).

Pratiwi, P. S., Murtadho, F., \& Chan, S. M. (2015). Ilokusi Dan Perlokusi Dalam Tayangan Indonesia Lawak Klub. Arkhais - Jurnal Ilmu Bahasa Dan Sastra Indonesia, 7(2), 110. https://doi.org/10.21009/arkhais.072.08

Puspita Nagari, A. N. G. G. R. E. K., \& Wedawati, T. (2020). Tindak Tutur Perlokusi dan Prinsip Kerja Sama dalam Drama Meteor Garden《 流星花园》 2018 episode 1-10 Karya Lin Helong. Mandarin Unesa, 2(2). 
Putra, S. P., \& Yuana, C. (2019). Analisis Lokusi Ilokusi Perlokusi dalam Drama Koe Koi. MEZURASHII: Journal of Japanese Studies, 1(1).

Saubani, S. S. (2018). Prinsip-prinsip kesopanan dalam film animasi "Moana" karya John Grierson (Suatu kajian Pragmatik). Fakultas Ilmu Budaya, Universiti Sam Ratulangi, 1-19.

Sendilatta, E. C. (2013). Analisis Tindak Tutur pada Film "Garuda di Dadaku" Karya Ifa Ifansyah. Jurnal Artikulasi, 7(1).

Tumalun, t. J. E., Jansen, f. T., \& Manus, j. A. (2019). Tindak Penolakan dalam Film Twilight Karya Catherine Hardwicke (suatu analisis pragmatik). Jurnal Elektronik Fakultas Sastra Universitas Sam Ratulangi, 4.

Wiranty, W. (2015). Tindak Tutur dalam Wacana Novel Laskar Pelangi Karya Andrea Hirata (Sebuah Tinjauan Pragmatik). Jurnal Pendidikan Bahasa, 4(2), 294304.

Wijayanti, D. N. (2014). Tindak Tutur Tokoh dalam Novel Berkisar Merah Karya Ahmad Tohari. Skripsi. Yogyakarta: Universitas Negeri Yogyakarta. 